\title{
METHOD OF SAMPLING IN A STUDY OF OLDER PEOPLE WITH A COMPARISON OF RESPONDENTS AND NON-RESPONDENTS
}

\author{
J. S. MILNE, M. M. MAULE, AND J. WILLIAMSON \\ Geriatric Research Unit, Royal Victoria Hospital, Edinburgh, 4
}

A longitudinal study of ageing persons 62 years and upwards was begun in Edinburgh on 31 January 1968. An attempt was made to select a cohort representative of the elderly population. This paper describes how the sample was drawn, what success was achieved in examining it, and how an attempt was made to compare respondents and nonrespondents.

Edinburgh is divided into 23 city wards in 10 of which one of us (J.W.) and colleagues provide a geriatric service. The sample was drawn from these 10 wards, contact being made with persons in the sample through their general practitioners. Ninetyfive general practitioners were working in 50 practices with premises in this area. The plan was explained to the doctors, 91 of whom agreed to co-operate and allowed us access to their lists of patients held by the Edinburgh Executive Council.

A census was made from the records of the Executive Council of the name, address, date of birth, and National Health Service number of all those persons born in 1905 or earlier who lived in the defined area and who were on the list of a doctor with a surgery address in that area. There were 26,903 such persons. This population excludes those who were not on a doctor's list and those who lived in the area but attended a doctor with a surgery address outside the area. The National Health Service number helps to trace persons who have died as well as the living.

From this population of 26,903 a random sample of 936 persons was drawn. The sample was classified according to the doctor and each doctor was given a list of his patients included in the sample. The doctors visited these people, explained the study to them, and told the Research Unit of those who were willing to come for examination. These subjects were examined between 31 January 1968, and 31 January 1970.

The sample of 936 persons contained 188 who did not qualify for inclusion in the sample as defined above. The reasons for excluding these 188, who amount to $20 \%$ of the names drawn, were:

$\begin{array}{lr}\text { Death before } 31 \text { January } 1968 & 64 \\ \text { Duplicate random numbers } & 17 \\ \text { Born after } 1905 \text { or resident outside the } & \\ \quad \text { defined area } & 21 \\ \text { Left Edinburgh (statement by G.P.) } & 13 \\ \text { Could not be traced (statement by G.P.) } & \\ \quad \text {-name not on electoral roll } & 65 \\ \text { Could not be traced (statement by G.P.) } & \\ \text { - name is on electoral roll } & 8\end{array}$

Some of the group that could not be traced are the 'ghosts' familiar to all general practitioners in Great Britain. Their cards have usually been in the doctors' files for many years and the patients themselves have long ago moved away or died. Many of the names date back to the partial health service which operated under the National Health Insurance Act, the records of which were absorbed into the National Health Service in 1948. Failure to locate these people is not so much a failure by the investigators as a reflection of an administrative difficulty.

Of the $\mathbf{7 4 8}$ persons who qualified for inclusion in the sample, 487 were examined $(65 \%), 212$ refused $(28.5 \%), 45$ died after the survey began without being examined $(6 \%)$, and 4 moved away after the survey began without being examined $(0 \cdot 5 \%)$.

The next step was to try to compare respondents and non-respondents. From the Executive Council's files only age and sex are available. Marital state is not always recorded. Table I shows the sex distribu-

TABLE I

RESEARCH SAMPLE OF 748 PEOPLE AGED 62 YEARS OR MORE

\begin{tabular}{c|c|c}
\hline & Examined & Not Examined \\
\hline $\begin{array}{l}\text { Male } \\
\text { Female }\end{array}$ & 216 & 69 \\
271 & 192 \\
\hline 487 & 261 \\
\hline
\end{tabular}

$Z=5 \cdot 14 ; P<0.01$. 
tion for the sample of 748 persons divided into those examined and those not examined. The proportion of women in the not examined group is significantly higher than in the group who were examined.

The 1966 sample census for Edinburgh published by the Registrar General reports 2,035 men and 3,960 women of 65 years and over. The research sample of 748 people born in 1905 or earlier contains 227 men and 400 women aged 65 years and over. Testing the difference between these proportions gives $Z=1.00$ and $P>0.05$ (Table II).

TABLE II

PERSONS AGED 65 YEARS OR MORE IN 1966 EDINBURGH SAMPLE CENSUS AND IN RESEARCH SAMPLE

\begin{tabular}{l|c|c}
\hline & Census & Sample \\
\hline Male & 2,035 & 227 \\
Female & 3,960 & 400 \\
\hline & 5,995 & 627 \\
\hline
\end{tabular}

$Z=1 \cdot 00 ; P>0.05$

The 487 persons aged 62 and over who were examined in the sample of 748 included 168 men and 231 women of 65 years and over. The proportion of men is significantly higher than that of the 1966 sample census $(Z=3.08, P<0.01)$.

Hence the total sample of 748 appears to have a sex distribution similar to that of the population of Edinburgh but the examined part of the sample does not.

TABLE III

AGE RANGES OF PERSONS EXAMINED IN RESEARCH SAMPLE (487) AND IN 1966 EDINBURGH SAMPLE CENSUS

\begin{tabular}{|c|c|c|c|c|}
\hline \multirow{2}{*}{$\begin{array}{l}\text { Age } \\
60-64 \\
62-64 \\
65-69 \\
70-74 \\
75+\end{array}$} & \multicolumn{2}{|c|}{$\underset{\mathbf{M}}{\text { Examined Group }} \mathbf{F}$} & \multicolumn{2}{|c|}{ Census $\mathrm{F}$} \\
\hline & $\begin{array}{l}-\overline{48} \\
76 \\
39 \\
53\end{array}$ & $\begin{array}{l}40 \\
98 \\
55 \\
78\end{array}$ & $\begin{array}{r}1,297 \\
827 \\
579 \\
629\end{array}$ & $\begin{array}{l}1,570 \\
1, \overline{368} \\
1,120 \\
1,472\end{array}$ \\
\hline & 216 & 271 & & \\
\hline
\end{tabular}

Table III gives the age distribution of the examined group (487) of the sample of 748 people, and of the 1966 sample census. It shows that it is possible to compare the age distribution of men and of women in the examined group and in the 1966 census for ages 65-69, 70-74, and 75+. Table IV shows that by testing the difference between the proportions of men and women separately in these three age ranges in the examined group and in the 1966
TABLE IV

COMPARISON OF AGE RANGES IN PERSONS EXAMINED FROM RESEARCH SAMPLE AND 1966 SAMPLE CENSUS

\begin{tabular}{|c|c|c|c|c|c|}
\hline Age Range & Sex & $\underset{\text { Group }}{\text { Examined }}$ & $\begin{array}{c}1966 \\
\text { Census }\end{array}$ & $\mathbf{Z}$ & $\mathbf{P}$ \\
\hline $\begin{array}{c}65-69 \\
70-74 \\
75+\end{array}$ & $\begin{array}{l}\mathbf{M} \\
\mathbf{M} \\
\mathbf{M}\end{array}$ & $\begin{array}{l}76 \\
39 \\
53\end{array}$ & $\begin{array}{l}827 \\
579 \\
629\end{array}$ & $\begin{array}{l}1.00 \\
1.25 \\
0.27\end{array}$ & $\begin{array}{l}>0.050 \\
>0.05 \\
>0.05\end{array}$ \\
\hline Total $>65$ & $\mathbf{M}$ & 168 & 2,035 & & \\
\hline $\begin{array}{c}65-69 \\
70-74 \\
75+\end{array}$ & $\begin{array}{l}\mathbf{F} \\
\mathbf{F} \\
\mathbf{F}\end{array}$ & $\begin{array}{l}98 \\
55 \\
78\end{array}$ & $\begin{array}{l}1,368 \\
1,120 \\
1,472\end{array}$ & $\begin{array}{l}0.91 \\
1 \cdot 38 \\
0.94\end{array}$ & $\begin{array}{l}>0.05 \\
>0.05 \\
>0.05\end{array}$ \\
\hline Total $>65$ & $\mathbf{F}$ & 231 & 3,960 & & \\
\hline
\end{tabular}

sample census, no statistically significant differenc항 emerges.

It would appear that the examined group has ar significantly different sex distribution from the्छ Edinburgh population, i.e. a deficiency of womenN in the examined group, but each sex has an age distribution which does not differ from that in theEdinburgh population.

Further comparison of respondents and non: respondents was made by sending to generap practitioners questionnaries relating to the 212 persons who refused examination and to a randon sample of 209 of those 487 persons who were examined. The questionnaire asked whether फ़ंळ patient had ever had hospital care and whether hes or she had had any of nine physical condition (ischaemic heart disease, intermittent claudication: chronic bronchitis, peptic ulcer, hiatus hernia $\Phi_{\infty}$ urinary tract infection, arthropathy of hip or knee without generalized arthropathy, rheumatoid arth응 ritis, stroke) or any of three mental conditions (anxiety, depression, dementia).

Table $\mathrm{V}$ shows the response to the questionnaire Adequate information was available for 168 res $\frac{\rho}{\zeta}$ pondents ( 84 male, 84 female) and 174 non-respon'dents (39 male, 135 female). Reasons for there being. no information available in the questionnaires of $1 \mathrm{~b}$ respondents and 22 non-respondents were death oB doctor, retirement of doctor, refusal by doctorg

\section{TABLE V}

REPLIES TO A OUESTIONNAIRE SENT TO PRACTITIONERS ABOUT RESPONDENTS AND NON-RESPONDENTS IN S
THE RESEARCH SAMPLE

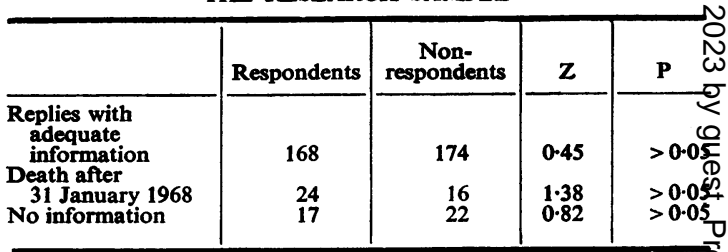


TABLE VI

COMPARISON OF ASSESSMENT BY PRACTITIONERS AND RESEARCH UNIT ON MALE RESPONDENTS $(\mathbf{N}=\mathbf{8 4})$ (Prevalence in percentages)

\begin{tabular}{l|r|r|r|r}
\hline & G.P. & $\begin{array}{c}\text { Research } \\
\text { Unit }\end{array}$ & $Z$ & Z \\
\hline Hospital care & 90.5 & 96.4 & 1.55 & $>0.05$ \\
Ischaemic heart disease & 27.4 & 22.6 & 0.72 & $>0.05$ \\
Intermittent claudication & 13.1 & 13.1 & 0.00 & $>0.05$ \\
Chronic bronchitis & 21.4 & 44.1 & 3.24 & $<0.01$ \\
Peptic ulcer & 22.6 & 22.6 & 0.00 & $>0.05$ \\
Hiatus hernia & 3.6 & 6.0 & 0.73 & $>0.05$ \\
Urinary tract infection & 8.3 & 13.0 & 0.98 & $>0.05$ \\
Arthropathy (knee or hip) & 18.0 & 19.0 & 0.17 & $>0.05$ \\
Rheumatoid arthritis & 3.6 & 1.2 & 1.00 & $>0.05$ \\
Stroke & 6.0 & 6.0 & 0.00 & $>0.05$ \\
Anxiety state & 13.0 & 13.0 & 0.00 & $>0.05$ \\
Dementia & 2.4 & 2.4 & 0.00 & $>0.05$ \\
Depressive illness & 10.7 & 10.7 & 0.00 & $>0.05$ \\
& & & & \\
\hline
\end{tabular}

TABLE VII

COMPARISON OF ASSESSMENT BY PRACTITIONERS AND RESEARCH UNIT ON FEMALE RESPONDENTS $(\mathrm{N}=84)$ (Prevalence in percentages)

\begin{tabular}{|c|c|c|c|c|c|}
\hline & G.P. & $\begin{array}{c}\text { Research } \\
\text { Unit }\end{array}$ & $\mathbf{Z}$ & $\mathbf{P}$ & \\
\hline Hospital care & $82 \cdot 2$ & & $2 \cdot 10$ & 0.01 & $<\mathrm{P}<0.05$ \\
\hline disease & $14 \cdot 3$ & $13 \cdot 0$ & 0.19 & $>0.05$ & \\
\hline $\begin{array}{l}\text { Intermittent } \\
\text { claudication } \\
\text { Chronic bronchitis } \\
\text { Peptic ulcer } \\
\text { Hiatus hernia }\end{array}$ & $\begin{array}{l}2 \cdot 4 \\
8 \cdot 3 \\
7 \cdot 1 \\
8 \cdot 3\end{array}$ & $\begin{array}{r}4 \cdot 8 \\
16 \cdot 7 \\
8 \cdot 3 \\
8 \cdot 3\end{array}$ & $\begin{array}{l}0.86 \\
1.65 \\
0.29 \\
0.00\end{array}$ & $\begin{array}{l}>0.05 \\
>0.05 \\
>0.05 \\
>0.05\end{array}$ & \\
\hline $\begin{array}{l}\text { Urinary tract } \\
\text { infection }\end{array}$ & $26 \cdot 0$ & $37 \cdot 0$ & 1.55 & $>0.05$ & \\
\hline $\begin{array}{l}\text { Arthropathy } \\
\text { (knee or hip) } \\
\text { Rheumatoid arthritis } \\
\text { Stroke } \\
\text { Anxiety state } \\
\text { Dementia } \\
\text { Depressive illness }\end{array}$ & $\begin{array}{r}22 \cdot 6 \\
7 \cdot 1 \\
8 \cdot 2 \\
23 \cdot 0 \\
8 \cdot 3 \\
18 \cdot 0\end{array}$ & $\begin{array}{r}36 \cdot 9 \\
7 \cdot 1 \\
7 \cdot 1 \\
29 \cdot 0 \\
9 \cdot 5 \\
13 \cdot 0\end{array}$ & $\begin{array}{l}2.04 \\
0.00 \\
0.29 \\
0.88 \\
0.27 \\
0.88\end{array}$ & $\begin{aligned} & 0.01 \\
> & 0.05 \\
> & 0.05 \\
> & 0.05 \\
> & 0.05 \\
> & 0.05\end{aligned}$ & $<P<0.05$ \\
\hline
\end{tabular}

doctor willing but could not find record, doctor answered most but did not return all questionnaires, patient moved away.

Replies by practitioners to the questionnaires about persons who had been examined were compared with the research unit's assessment separately for men and women (Tables VI and VII). In each Table the percentage prevalence of each condition is recorded as assessed by the practitioner and by the research unit. For each condition the difference between these percentages is tested. The only conditions in which a statistically significant difference exists between the assessments of the practitioner and the research unit are chronic bronchitis in men, for which the research unit's prevalence is double that of the practitioner's, and hospital care and arthropathy of hip or knee in women. These differences are explained in the discussion.

There being reasonable agreement between the practitioners and the research unit about prevalence in persons examined, the next step is to compare prevalence as described by practitioners in respondents and non-respondents separately for men and women. This comparison is shown in Tables VIII and IX where the prevalence of each condition in respondents and non-respondents is recorded as a percentage and the difference between corresponding percentages is tested. Statistically significant differences exist in men in the number who had had hospital care, ischaemic heart disease, intermittent claudication, and peptic ulcer, and in women in the number who had had hospital care, hiatus hernia, and urinary tract infection. There are, therefore, highly significant differences between respondents and non-respondents based on information from the general practitioner.

TABLE VIII

COMPARISON OF ASSESSMENT BY PRACTITIONERS IN MALE RESPONDENTS $(\mathrm{N}=84)$ AND MAIE NON-RESPONDENTS $(\mathrm{N}=39$ ) (Prevalence in percentages)

\begin{tabular}{|c|c|c|c|c|}
\hline & $\begin{array}{c}\text { Respon- } \\
\text { dents }\end{array}$ & $\begin{array}{c}\text { Non- } \\
\text { respon- } \\
\text { dents }\end{array}$ & $\mathbf{Z}$ & $\mathbf{P}$ \\
\hline \multirow{6}{*}{$\begin{array}{l}\text { Hospital care } \\
\text { Ischaemic heart } \\
\text { disease } \\
\text { Intermittent } \\
\text { claudication } \\
\text { Chronic bronchitis } \\
\text { Peptic ulcer } \\
\text { Hiatus hernia } \\
\text { Urinary tract } \\
\text { infection } \\
\text { Arthropathy } \\
\text { (knee or hip) } \\
\text { Rheumatoid } \\
\text { arthritis } \\
\text { Stroke } \\
\text { Anxiety state } \\
\text { Dementia } \\
\text { Depressive illness }\end{array}$} & $90 \cdot 5$ & $79 \cdot 6$ & 1.96 & $<0.05$ \\
\hline & 27.4 & $7 \cdot 7$ & 3.03 & $<0.01$ \\
\hline & $\begin{array}{r}13 \cdot 1 \\
21 \cdot 4 \\
22 \cdot 6 \\
3 \cdot 6\end{array}$ & $\begin{array}{r}0.0 \\
20.5 \\
7.7 \\
0.0\end{array}$ & $\begin{array}{l}3.61 \\
0 \cdot 12 \\
2.40 \\
1.80\end{array}$ & $\begin{array}{r}<0.01 \\
>0.05 \\
0.01 \\
>0.05\end{array}<P<0.05$ \\
\hline & $8 \cdot 3$ & $7 \cdot 7$ & $0 \cdot 11$ & $>0.05$ \\
\hline & 18.0 & 13.0 & 0.74 & $>0.05$ \\
\hline & $\begin{array}{r}3.6 \\
6.0 \\
13.0 \\
2.4 \\
10.7\end{array}$ & $\begin{array}{r}2 \cdot 6 \\
7 \cdot 7 \\
13 \cdot 0 \\
2 \cdot 6 \\
\mathbf{7 \cdot 7}\end{array}$ & $\begin{array}{l}0.31 \\
0.33 \\
0.00 \\
0.06 \\
0.52\end{array}$ & $\begin{array}{l}>0.05 \\
>0.05 \\
>0.05 \\
>0.05 \\
>0.05\end{array}$ \\
\hline
\end{tabular}

TABLE IX

COMPARISON OF ASSESSMENT BY PRACTITIONERS IN FEMALE RESPONDENTS $(\mathrm{N}=84)$ AND FEMALE NONRESPONDENTS $(\mathrm{N}=135)$ (Prevalence in percentages)

\begin{tabular}{|c|c|c|c|c|}
\hline & $\begin{array}{c}\text { Respon- } \\
\text { dents }\end{array}$ & $\begin{array}{l}\text { Non- } \\
\text { respon- } \\
\text { dents }\end{array}$ & $\mathbf{Z}$ & $\mathbf{P}$ \\
\hline Hospital care & $82 \cdot 2$ & $61 \cdot 0$ & 3.56 & $<0.01$ \\
\hline $\begin{array}{l}\text { 1schaaemic hea } \\
\text { disease }\end{array}$ & $14 \cdot 3$ & $10 \cdot 4$ & 0.87 & $>0.05$ \\
\hline $\begin{array}{l}\text { claudication } \\
\text { Chronic bronchitis } \\
\text { Peptic ulcer } \\
\text { Hiatus hernia }\end{array}$ & $\begin{array}{l}2 \cdot 4 \\
8 \cdot 3 \\
7 \cdot 1 \\
8 \cdot 3\end{array}$ & $\begin{array}{l}1 \cdot 5 \\
9 \cdot 6 \\
6 \cdot 7 \\
0.7\end{array}$ & $\begin{array}{l}0 \cdot 45 \\
0 \cdot 33 \\
0 \cdot 11 \\
2 \cdot 45\end{array}$ & $\begin{aligned} &> 0.05 \\
&>0.05 \\
&>0.05 \\
& 0.01<P<0.05\end{aligned}$ \\
\hline $\begin{array}{l}\text { Urinary tract } \\
\text { infection } \\
\text { int }\end{array}$ & $26 \cdot 0$ & $12 \cdot 0$ & $2 \cdot 55$ & $0.01<\mathrm{P}<0.05$ \\
\hline $\begin{array}{l}\text { (knee or hip) } \\
\text { Rheumatoid }\end{array}$ & $22 \cdot 6$ & $20 \cdot 0$ & 0.46 & $>0.05$ \\
\hline $\begin{array}{l}\text { arthritis } \\
\text { Stroke } \\
\text { Anxiety state } \\
\text { Dementia } \\
\text { Depressive illness }\end{array}$ & $\begin{array}{r}7 \cdot 1 \\
8 \cdot 3 \\
23 \cdot 0 \\
8 \cdot 3 \\
18 \cdot 0\end{array}$ & $\begin{array}{r}3 \cdot 7 \\
2 \cdot 2 \\
17 \cdot 0 \\
3 \cdot 0 \\
12 \cdot 0\end{array}$ & $\begin{array}{l}1.03 \\
1.85 \\
1.09 \\
1.61 \\
1.19\end{array}$ & $\begin{array}{l}>0.05 \\
>0.05 \\
>0.05 \\
>0.05 \\
>0.05\end{array}$ \\
\hline
\end{tabular}




\section{Discussion}

It is easy in Great Britain, where there is a National Health Service in which most people register with a doctor, to define a population from which a random sample can be drawn. The sex differences described above between respondents and non-respondents show how difficult it is to examine a sufficient number of persons in such a sample to justify making inferences about the population. The comparison of prevalence figures from general practitioners and from the research unit on persons examined shows differences for which explanation can be offered. The research unit's prevalence of chronic bronchitis $(44 \cdot 1 \%)$ is double that of the practitioners' $(21 \cdot 4 \%)$. For the purpose of this enquiry the research unit defined chronic bronchitis as the production of phlegm on most days for at least three months each year. The practitioners' criterion is unknown. The difference is in the direction which would be expected. The difference in statements about hospital care may arise because the research unit takes a history covering the subject's whole life whereas, especially in the elderly, the practitioner may not have such full information. This could account for the higher figure for the research unit's history of hospital care. The difference in prevalence of arthropathy in the knee or hip in women may be because the research unit recorded any limitation of movement in the knee or hip as arthropathy, whereas the practitioner would presumably record only those who had symptoms.

It seems, therefore, that there is reasonable agreement between the practitioners and the research unit about respondents and that the above explanations could account for the differences found. There are, however, no simple explanations of the differences described by the practitioners between respondents and non-respondents. Non-respondents, both men and women, seem to have had significantly less hospital care than respondents. Male nonrespondents seem to have less vascular disease and peptic ulcer and female non-respondents less hiatus hernia and urinary tract infection. It might be concluded that the healthier subjects are less willing to be examined in a study of this kind. Speculation might suggest that the preponderance of women in the non-respondents is because elderly women are more fully occupied than elderly men and less willing to spare time for examination.

The importance of investigating non-respondents is shown in Cochrane's (1954) review of the evidence that there is an increasing percentage of abnormal chest $x$-rays as increasing pressure is brought to bear on a population to submit to $x$-ray examination.
He also found in the Rhondda Fach decreasing success with increasing age, the success rate at age 65 being $70 \%$. Five other surveys mentioned by hin also showed a decrease in success as age rose? Cochrane also found in older people that fewe $\overrightarrow{5}$ women than men were $x$-rayed.

In the Report on the Edinburgh $x$-ray Campaigt of 1958 (Seiler, Welstead, and Williamson, 1958) i is stated that $77.9 \%$ of all males and $75.6 \%$ of al局 females over the age of 15 were $x$-rayed, but at ages of 60 years and over the percentage fell to 67.9 for men and 63.5 for women. Following the mairo Edinburgh Campaign an effort was made to $x$-ray non-respondents in one city ward (Fletcher, Mairw Sklaroff, and Williamson, 1959). This raised the response by $6.5 \%$ and showed a higher prevalence of pulmonary tuberculosis than that found in the main campaign.

Both these groups showed a health differences between respondents and non-respondents. The experience of the present survey in respect of the success rate in older people and in women agrees $\rightarrow$ with that of these workers. In contrast to theif findings, non-respondents seem to be healthier than respondents but the present survey was not concerne with tuberculosis.

$8 \overrightarrow{0}$

Cartwright (1959), in an investigation of famietes and individuals who did not co-operate in a same survey, found a similar distribution of numbers $=00$ consultations with the general practitioner in the previous year in respondents and non-respondent which might be interpreted as meaning no differenco in health between respondents and non-respondents? She reported a declining success rate in surveyin $\overrightarrow{\vec{g}}$ married people as age increased. In persons of $6 \$$ years and over the success rate was $74 \%$ of the sample drawn. This seems comparable with the. present survey's success rate of $65 \%$ when it is remembered that Cartwright's study was by inter? view without clinical examination whereas the present survey included a two-hour physical and one-hour psychiatric examination.

Akhtar (1970) in Glasgow visited personally the non-respondents in a survey of the elderly. He found them in marginally better physical health than respondents; there was no obvious difference io mental health. It seems possible that both the Glasgow and Edinburgh surveys tend to over estimate the prevalence of some diseases in the elderly.

The W.H.O. Report on Sampling Methods i Morbidity Surveys and Public Health Investigations (1966) classified major non-sampling errors i surveys as (a) coverage errors, (b) observationaf errors, and $(c)$ processing errors. Experience in thळo 
present survey suggests that since the latter two sources of error lie in the province of the investigator and his staff, and do not depend on subject cooperation, reduction of such error will depend mainly on the zeal with which attempts are made to eliminate it. On the other hand, the technique of approach to the subjects through the general practitioner meant that a refusal received by him prevented further approach to the subject by the investigators. The size of the coverage error depended partly on how interested the practitioner was in persuading his patients to co-operate, and this was largely beyond the control of the investigator. Direct approach to the public with a request to submit to elaborate clinical examination would quite rightly not be popular with the practitioners. That part of the coverage error due to death or removal to another district before examination could be reduced by doing the survey in the shortest possible time.

\section{SUMMARY}

A random sample of 936 men and women aged 62 and upwards was drawn from the population records of 26,903 old people in Edinburgh; 188 $(20 \%)$ did not qualify for inclusion when further investigated. Of 748 available for examination 487 (65\%) were examined.

Comparison of respondents and non-respondents showed an excess of women in the non-respondents.
Age distribution in respondents (for sexes separately) did not differ from the 1966 sample census.

Comparison of information about the same respondents from general practitioners and from the research unit gave reasonable agreement. Some explanation of the differences is possible.

Comparison of respondents and non-respondents using information from the general practitioners revealed significantly less hospital care, vascular disease, and peptic ulcer in male non-respondents and significantly less hospital care, hiatus hernia, and urinary tract infection in female nonrespondents.

\section{REFERENCES}

AKhtar, A. (1970). Personal communication.

CARTWRIGHT, A. (1959). The families and individuals who did not cooperate on a sample survey. Milbank mem. Fd Quart., 37, 347.

Cochrane, A. L. (1954). The detection of pulmonary tuberculosis in a community. Brit. med. Bull., 10, 91.

Fletcher, W. B., MaIr, J. M., Sklaroff, S. A., and Williamson, J. (1959). Observations on non-attendance in a community chest $x$-ray survey. Tubercle (Edinb.), 40, 82.

Seiler, H. E., Welstead, A. G., and Williamson, J. (1958). Report on Edinburgh $x$-ray Campaign, 1958. Tubercle (Edinb.), 39, 339.

W.H.O. (1966). Technical Report Series No. 336. Sampling methods in morbidity surveys and public health investigations. Geneva. 